\title{
CSR Policies: Effects on Labour Productivity in Spanish Micro and Small Manufacturing Companies
}

\author{
Pablo Esteban Sánchez • Sonia Benito-Hernández
}

\begin{abstract}
This paper analyses empirical evidence of efforts to enable Spanish micro and small manufacturing companies to boost their labour productivity rates through the development of the main pillars of their corporate social responsibility (CSR) policies. This study aims to develop new approaches and sensibilities towards work from an ethical, values (virtues) and CSR perspective, showing how internal dimensions of CSR, such those related to relationships with employees and responsibility in processes and product quality, can improve labour performance and labour efficiency, thereby contributing to a better society. The results of a sample of 929 small businesses indicate that the social responsibility policies that most contributed to a short-term increase in labour productivity are those related to internal aspects of the company, in particular its involvement in the quality of processes and products, promotion of innovation and employee care. However, the impact on labour productivity of CSR policies related to external factors, such as relationship with stakeholders and environmental concern, could not be empirically proven in this paper.
\end{abstract}

\author{
Abbreviations \\ CFP Corporate financial performance \\ CSP Corporate social performance \\ CSR Corporate social responsibility \\ ESEE Encuesta sobre Estrategias Empresariales (Survey \\ on Business Strategy) \\ GDP Gross domestic product \\ GVA Gross value added \\ MBA Master in Business Administration \\ R\&D Research \& Development \\ SEPI Sociedad Estatal de Participaciones Industriales \\ (National holding for share portfolio in industry) \\ SMEs Small- and medium-sized enterprises \\ UK United Kingdom
}

\section{Introduction}

Most of the world's developed countries are being affected by a global recession, with falls in gross domestic product (GDP) and increases in unemployment rates. From mid2008 and during 2009, the annual growth rate of real labour productivity fell markedly, but in the long term this crisis does not need to bring about lower labour productivity. According to the European Competitiveness Report 2010, labour productivity in the EU-27 appears to be recovering faster than the GDP, due to the adjustment lags of employment. As highlighted in that report, recession includes two types of mechanisms: those that negatively impinge on economic efficiency and those that improve its ability to increase productivity in the future (European Commission 2010).

The recovery of productivity growth rates observed during 2009 suggests that the labour market has made a marked adjustment in hours and workers employed. This 
has resulted in a moderation in the drop in productivity growth. Many governments in Europe are working to boost productivity growth. Among them, the UK government has targeted five drivers of productivity (Myers 2009):

- Skills;

- Investment;

- Innovation;

- Competition;

- Enterprise and entrepreneurship.

However, companies can make other efforts during periods of recession to boost their competitiveness and productivity. Thus, some authors have linked corporate social responsibility (CSR) to competitiveness and labour productivity. They have found a positive link between CSR and a good reputation, and improved labour efficiency and labour productivity (Stuebs and Sun 2010; Fombrun 1996; Podolny 1993).

Stuebs and Sun (2010) define labour efficiency, labour productivity, labour costs and their relationship with reputation. Labour efficiency is defined as a labour resource utilization measure that is a function of labour productivity per unit of labour cost:

Labour efficiency $=\frac{\text { Labour productivity }}{\mathrm{T} 1}$.

Labour cost

Labour cost

employee as follogures the average labour cost per

Total labour cost

Labour cost $=\frac{\text { Employees }}{\text { Total labour cost }}$.

Given the limitations of our data, we measure labour productivity in this paper as follows:

Labour productivity $(\mathrm{SA})=\frac{\text { Sales }}{\text { Employees }}$

or

$\mathrm{T}, \quad$. . ..,. $\quad$ Value of productivity

Labour productivity $(\mathrm{PE})=\frac{}{\text { Employees }}$

Both sales and value of production are total output measures.

Other authors (Stuebs and Sun 2010) have used income before labour costs to calculate labour productivity:

Labour productivity $=\frac{\text { Income }}{\text { Employees }}$.

They obtained the same results using the variable sales instead of the income. Due to data limitations, sales and value of production were chosen as output measures in this paper.

Substituting Eqs. 2 and 3a in Eq. 1, we obtain labour efficiency Eq. 5:
Labour efficiency $=\frac{\text { Sales }}{\text { Total Labour costs }}$.

Equation 5 is consistent with the concept of economic efficiency, which refers to the production of goods and services from a given quantity of resources (Sullivan and Sheffrin 2003, p. 15).

After more than six decades, academics and practitioners still do not agree upon a definition of CSR. One of the first authors defined CSR as the obligations of businessmen to adopt policies, make decisions and undertake desirable actions in terms of the objectives and values of society (Bowen 1953). Six decades later, The European Commission defined CSR as 'a concept whereby companies decide voluntarily to contribute to a better society and a cleaner environment' (Commission of the European Communities 2001) and 'a concept whereby companies integrate social and environmental concerns in their business operations and in their interaction with their stakeholders on a voluntary basis' (European Commission 2003).

Vilanova et al. (2009) clarified the nature of the positive relationship between CSR and the dimensions of competitiveness, among which were efficiency and productivity. Common justifications for a company to adopt CSR policies include the value of a good reputation, cost reductions and operating efficiencies, competitive advantage through product differentiation and the development of technologies, and keeping employees motivated (Wood 2010; Weber 2008; De Schutter 2008; Lee 2008).

Stuebs and Sun (2010) proposed a CSR and competitiveness framework based on Vilanova et al. (2009). In that framework, they explained the positive relationship between CSR and Competitiveness through improvements in business reputation due to good CSR policies. They also explained the relationship between CSR and competitiveness and incorporated business reputation as an important driver in initiating CSR activities. Then, they explored the relationships between business reputation and labour productivity, concluding that good business reputation can produce labour efficiency and labour productivity benefits.

Business Reputation is defined as a 'perceptual representation of a company's past actions and future prospects that describe the firm's overall appeal to all its key constituents when compared to other leading rivals' (Fombrun 1996, p. 72). Reputation is a valued intangible asset (Schnietz and Epstein 2005) and acts as a fundamental driver to initiate and implement CSR (Vilanova et al. 2009, p. 64). According to Vilanova et al. (2009), business reputation is the key to channelling the impact that CSR policies have on competitiveness and its different dimensions.

This paper also considers the importance of micro companies and small businesses in terms of employment- 
in Spain, $49 \%$ of total employment and $50.5 \%$ of total gross value added (GVA) are linked to micro and small businesses (Ministry of Industry, Energy and Tourism of Spain 2012; European Commission 2011). According to the definition of the European Commission (recommendation 2003/361/CE, 2003), a small company is a company with less than 49 employees and a micro company has less than 10 employees.

The main contribution and purpose of this paper are to find empirical evidence of efforts that Spanish micro and small manufacturing companies can make to boost their labour productivity rates through the development of some of the main pillars of their CSR policies. This study aims to develop new approaches and awareness towards work from an ethical, values (virtues) and CSR perspective, showing how internal dimensions of CSR, such those related to relationships with employees and responsibility in processes and product quality, can improve labour performance and labour efficiency, thus contributing to a better society.

This paper first reviews the state of the art concerning the relationship among CSR, competitiveness and productivity in the "Literature Review" section. The remainder of the paper is organised as follows: the "Theoretical Model" section discusses the theoretical background and justification of the hypotheses that are empirically contrasted. The "Data Analysis and Methodology" section describes the sample collection, construction of variables, analysis methodology and regression results. Finally, the "Conclusions" section discusses the implications and limitations of the evidence found.

\section{Literature Review}

The Importance of Corporate Social Responsibility (CSR) Discussion

The CSR construct has been widely discussed from different perspectives by academics and practitioners since the 1970s. Some authors have considered CSR to be an ethical question (Mintzberg 1983; Jones 2003; Moore 2003), while others have considered it to be a social and citizenship issue (van Luijk 1999, 2005) or an indicator of social responsiveness (Carroll 1979; Wartick and Cochran 1985; Wood 1991). The last four authors developed a three-dimensional model of social responsiveness, including economic and social goals. Some scholars have adopted a stakeholder relationship perspective (Clarkson 1995; Jones 1995; Freeman 1984; Hopkins 2003). Others have introduced CSR in a business strategy framework (Porter 2003; Lantos 2001) that can improve corporate competitiveness and economic and financial performance, known as the Business Case for CSR. The Business Case for CSR argues that CSR policies can improve a company's competitiveness and, subsequently, its corporate economic and financial performance (Burke and Logsdon 1996).

All of these perspectives include multiple issues and topics. This paper could mention, among others, measurement, communication and reporting, strategy management, social responsibility conceptual discussion, social value creation, business value creation, implementation, employee satisfaction and environmental scanning. However, this work focuses on analysing the relationship between CSR and labour productivity under the business case framework of CSR for small and micro companies.

\section{CSR and Small and Micro Companies}

The differences between small and micro companies and larger companies make the implementation of CSR in the former an important subject for research. Size represents only one criterion; others include legal form, sector, orientation towards profit, national context, historical development and institutional structures (Spence 1999; Spence and Rutherfoord 2003, p. 4). The attributes that distinguish small and micro companies from big companies often present some disadvantages when they adopt social responsibility principles and policies. However, this kind of company also has some advantages which can be relied on to build social responsibility policies that can have a positive influence on their performance and in managing their relationships with the various operators they interact with. We can identify these differences in Table 1 .

CSR has basically focused on large firms, while CSR in small-sized companies has received relatively little attention (Grayson 2004; Spence 1999; Spence et al. 2000, 2003; Spence and Lozano 2000; Spence and Rutherfoord 2003; Spence and Schmidpeter 2003; Thompson and Smith 1991; Tilley 2000; Vyakarnam et al. 1997). This paper focuses on small and micro companies.

The Business Case of CSR: CSR and Its Relationship with Competitiveness

Many scholars have analysed the relationship between CSR and competitiveness within the business case framework for CSR (Vilanova et al. 2009). CSR can influence different dimensions of competitiveness.

In its European Competitiveness Report, the European Commission (2008) overviewed the links between CSR and competitiveness and examined the following six areas where the effects of CSR can be observed at the company level: (1) cost structure, concluding that evidence of cost reduction is mixed; (2) human resource performance, concluding that CSR has compelling positive effects on 
Table 1 CSR: micro company versus large company
Source author-compiled data based on Vicente Molina et al. (2004)

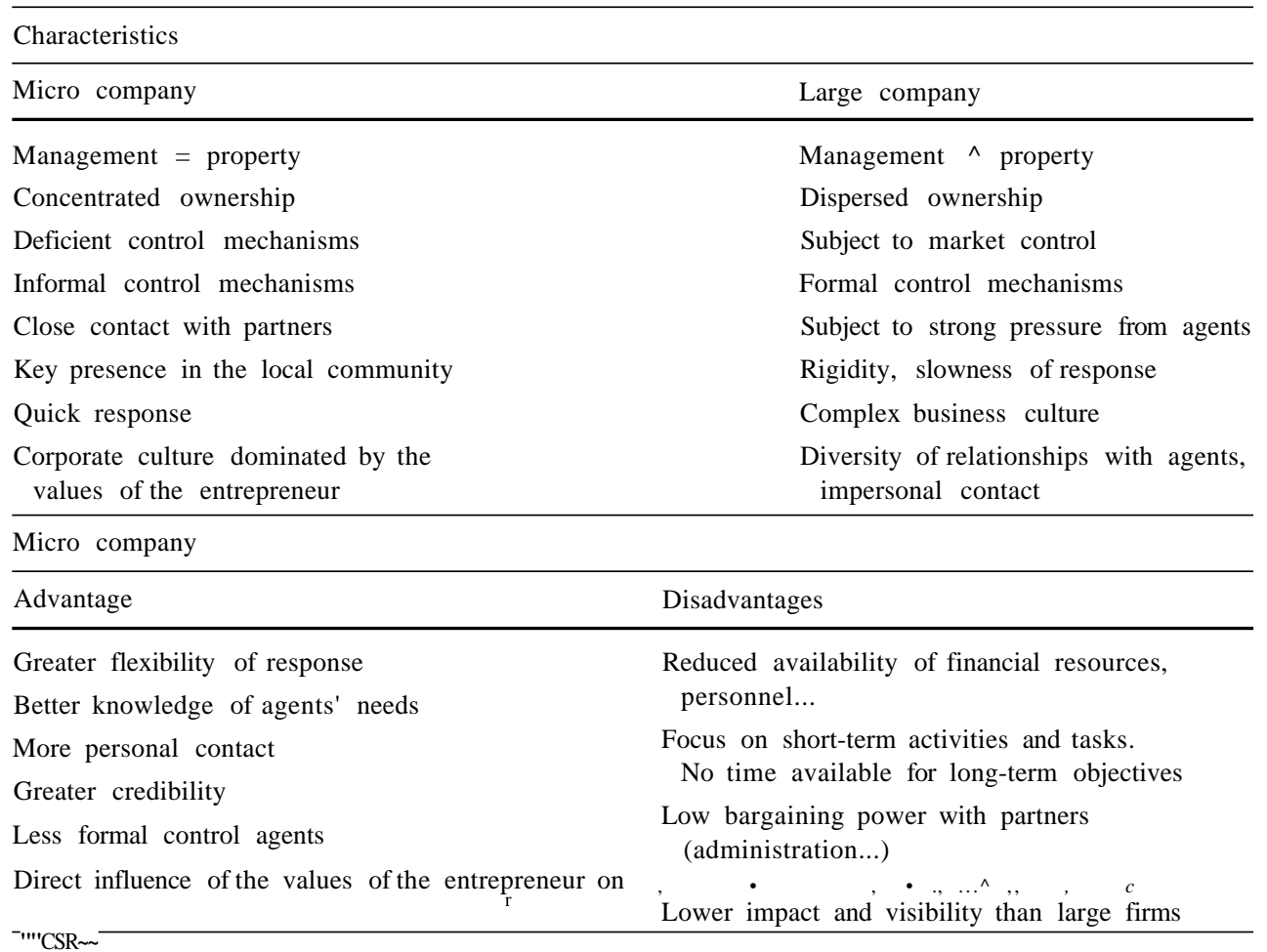

labour performance and the company's appeal when recruiting highly qualified employees, and at the same time identifying the positive effects of CSR on innovation thanks to diverse policies in workforce recruitment and knowledge of management improvements; (3) customer perspective, concluding that positive effects are mixed and depend on whether consumers are really willing to pay premium prices for socially responsible products; (4) innovation resulting from (a) engagement with diverse stakeholders, (b) addressing societal challenges related to the bottom of the pyramid, which the company can exploit in terms of business opportunities, or related to environmental milestones that the company has to overcome and (c) better CSR workplaces; (5) risk and reputation management, with evidence of positive effects of CSR in terms of risk mitigation and improvements in reputation; and (6) financial markets offering a positive relationship between CSR and corporate financial performance (CFP) and better access to finance. Finally, it concluded that 'The strongest evidence of a positive impact of CSR on competitiveness appears to be in the cases of human resources, risk and reputation management, and innovation. Positive links between CSR and competitiveness also exist but appear less strong or not so generally applicable in the case of cost structure, the customer perspective, and financial markets'.

The model that Vilanova et al. (2009) originally built and Vilanova's modified model (Stuebs and Sun 2010) contributed to clarifying the nature of the positive relationship between CSR and the performance dimensions of competitiveness.

Competitiveness can be interpreted as the strength of a company compared to its competitors (Murths and Lenway 1998), not only in tangible factors but also including intangible assets or capacities, such as reputation, key internal and external relations (Kay 1993), knowledge, relationships, or talent (Lowell 2007).

Vilanova et al. (2009) proposed five key dimensions of competitiveness:

(1) Performance, including standard financial measures, such as earnings, growth or profitability (Hamel and Prahalad 1989); (2) Quality, not only of products and services, but also the capacity to satisfy customer expectations (Barney 1991); (3) Productivity, in terms of higher production and lower use of resources (Porter 1985); (4) Innovation, including products and services, as well as management processes (Mintzberg 1993) and (5) Image, including corporate branding, in terms of building trust and reputation in the relationship with stakeholders (Kay 1993).

Stuebs and Sun (2010) proposed a revised CSR and competitiveness framework based on Vilanova et al. (2009). The framework explained the relationship between CSR and competitiveness and incorporated business reputation as an important driver to initiate CSR activities. 
CSR can improve business reputation which can in turn produce performance benefits. Good Business reputation can help create cost advantages (Podolny 1993) and is associated with company efficiencies (Stuebs and Sun 2009). A good reputation can improve trust and relationships with a number of stakeholders, which can lead to reduced costs and improved efficiencies. Podolny (1993) noted a number of cost reductions that can result from improved reputation.

One of the elements of competitiveness proposed by Vilanova et al. (2009) is CFP. The question of financial profitability and its relationship with CSR has been studied by many researchers (Orlitzky et al. 2003; Allouche and Laroche 2005). Many others have examined the relationship between company risk and CSR (Orlitzky and Benjamin 2001).

While it is true that empirical studies carried out in the 1970s produced confusing results, most of them found a positive correlation between CSR and economic performance (Orlitzky et al. 2003; Allouche and Laroche 2005) and a negative correlation between CSR and risk/volatility (Orlitzky and Benjamin 2001).

The confusing results obtained could have been caused by factors such as the following: difficulties in measuring, lack of rigour in statistical techniques, lack of consistency and problems with the heterogeneity of samples and the statistical methods, multicollinearity of the variables used and the non-use of control variables that can have an influence on the relationship, such as company size and the sector to which it belongs.: Despite this, research, bibliometric analyses (De Bakker et al. 2005) and recent meta analyses have produced a common stand which tends to overcome these problems (Allouche and Laroche 2005; Orlitzky et al. 2003; Orlitzky and Benjamin 2001; Frooman 1997; Wu 2006; Margolis et al. 2007), providing evidence of a positive correlation between CSR and economic performance. Margolis et al. (2007) concluded, After 35 years of research, the preponderance of evidence indicates a mildly positive relationship between corporate social performance (CSP) and CFP'. So, there is no compelling evidence that good CSP is too costly, and the preponderance of evidence points to the opposite conclusion: it is costly to be socially irresponsible.

Once the positive or negative relationship and the determining variables have been identified, it is important to analyse the type of relationship that exists between the main variables under research. There are a number of different theories on this, but the most widely accepted is the theory of the existence of a virtuous circle of

\footnotetext{
1 This paper has included these control variables, given that the sample is made up of small companies belonging to the industrial sector.
}

bidirectional value between CSR and a company's economic and financial results (Orlitzky 2005; Allouche and Laroche 2005). According to this theory, good financial results free up resources to undertake CSR activities (Waddock and Graves 1997), and good practices in CSR favour the company's financial results (Orlitzky et al. 2003; Orlitzky 2005). However, it is also evident that the positive link between CSR and a company's performance cannot be explained directly. Thus, these studies were criticised by Wood (2010) for not taking into account the different mediating mechanisms that facilitate the positive relationship between CSR and a company's financial performance.

Schreck (2011) also proposed a framework of reference to study and understand the relationship between CSR and CFP. This framework defined some internal mediating effects that can explain the positive relationship between CSR and CFP, such as employee satisfaction, innovativeness and efficiency gains, and some external mediating effects, such as reputation, lower risk, cost of capital and improved access to capital markets.

Numerous studies have tried to clarify the interaction between CSR and CFP, identifying some of the mediating effects like CSR business benefits. Weber (2008) mentioned other CSR benefits from different scholars' research, such as cost reduction (Schaltegger and Burritt 2005; Kong et al. 2002; Rondinelli and London 2002; Hansen 2004; Epstein and Roy 2001), efficiency gains (Heal 2005; Rondinelli and London 2002; Epstein and Roy 2001), improved image and reputation (Schaltegger and Burritt 2005; Hansen 2004; Epstein and Roy 2001; Rondinelli and London 2002), improved employee productivity (Heal 2005), increased recruitment potential (Hansen 2004; Turban and Greening 1997), employee motivation (Epstein and Roy 2001), increased competitiveness through process and product benefits (Porter and van der Linde 1998; Rondinelli and London 2002), access to capital and reduced capital costs (Heal 2005; Hansen 2004; Epstein and Roy 2001), market development (Kong et al. 2002; Hansen 2004), product development (Rondinelli and London 2002), risk management and reduction (Schaltegger and Burritt 2005; Heal 2005; Hansen 2004) and differentiation (Schaltegger and Burritt 2005).

Labour Productivity as a Dimension of Competitiveness

As mentioned in "The Business Case of CSR: CSR and Its Relationship with Competitiveness" section, productivity is also one of the dimensions of competitiveness (Vilanova et al. 2009). These authors considered productivity in terms of higher production and lower use of resources. Other authors have considered productivity a good proxy to 
competitiveness (Porter 1985). In this sense, higher production with a lower use of resources leads to greater competitiveness compared to rival companies.

\section{CSR and Its Relationship with Labour Productivity}

Some scholars have discussed the CSR effects on employee performance. In a theoretical case study, Heal (2005) concluded that CSR policies can improve labour productivity. This case study surveyed MBA students' attitudes towards potential employers and found that they were willing to take lower pay to work for companies with a more positive social image.

Heal (2005) also noted that employees work better if they are paid more, so labour productivity can improve if employees are paid more than market wages. Higher 'efficiency wages' may contribute to increasing the output sold per worker, thereby offsetting CSR costs and making CSR choices sustainable (Becchetti and Trovato 2011).

However, according to other authors, the relationship between labour costs and labour productivity is not clear. In theory, the good reputation of companies with good CSP can attract and motivate good employees (Roberts and Dowling 2002). It can generate a greater capacity for attracting talented and highly qualified workers (Greening, and Turban 2000). This can become a competitive advantage for the company by creating valuable intangible assets (Barney and Hansen 1994; Porter and Kramer 2002). It promotes a greater generation of specific knowledge and mechanisms that aid learning, by creating an environment that promotes voluntary attitudes of cooperation and competition (Axelrod 1984; Axelrod and Cohen 1999). This creates better learning environments and innovation and achieves greater performance from workers. In addition, these workers may be willing to earn less to work in a socially responsible company. The hypothesized changes in lower labour costs and higher labour productivity should result in increased labour efficiency (Stuebs and Sun 2010).

Moreover, employee motivation results in productivity benefits when a company has a good reputation for maintaining good relations with employees, and consequently this improves operational efficiency (Branco and Rodriguez 2006) and labour resource efficiency advantages (Fombrun 1996; Podolny 1993).

Some authors have found a positive link between a company's relationship with its employees and its financial performance (Schreck 2011). The good relationship with the community could also be turned into a competitive advantage by improving employee morale and boosting productivity (Porter and Kramer 2002).

Stuebs and Sun (2010) analysed the relationship between labour productivity and labour efficiency and business reputation as an important driver to initiate and develop a
CSR strategy to improve competitiveness. Despite the aforementioned, the relationship among business reputation, labour costs, labour productivity and labour efficiency is still not clear. Tensions exist, above all, with regard to labour costs. Workers are not always willing to accept lower remuneration to work in a company with a good reputation. Companies with a good reputation may often choose to pay their workforce more to maintain a good relationship with them. Consequently, labour costs increase and may even surpass the efficiencies gained in productivity, thereby bringing about a decrease in labour efficiency.

It can therefore be concluded that there is a positive relationship between reputation and productivity, but it is more difficult to explain its relationship with labour costs (Stuebs and Sun 2010).

Table 2 shows a summary of the literature review. The table is only for guidance and does not aim to be exhaustive.

\section{Theoretical Model}

After a review of the state of the art of the relationship between CSR and competitiveness, this work considers the theoretical and methodological contributions of Vilanova et al. (2009), Stuebs and Sun (2010), and Schreck (2011) to construct a model and framework for this research.

Most recent studies on the relationship between CSR and a company's financial results have analysed individual CSP components or mediating effects, rather than CSP as a whole. This highlights the multidimensional nature of the CSR construct, as it involves diverse stakeholders. The effects of CSR actions and policies on CFP depend on the nature of the CSR component involved (Schreck 2011).

According to this model design framework, the proposed model (Fig. 1) defines the different CSR and competitiveness dimensions.

The proposed model defines the following dimensions of CSR: (1) ethical dimension; (2) relationship with the community; (3) relationship with employees; (4) the environment; (5) communication of CSR policies; (6) good corporate governance: ownership and management; (7) responsibility in process quality; (8) responsibility in product quality; (9) market place activities; and (10) accountability and transparency.

These dimensions can be grouped by internal orientation (relationship with employees, good corporate governance: ownership and management, responsibility in process quality and responsibility in product quality) and external orientation (relationship with the community, environment, accountability and transparency, market place activities, communication of CSR policies and the ethical dimension-as it deals with an outward projection of the ethical principles and social values of the founders). 
Table 2 Literature review

\begin{tabular}{|c|c|}
\hline CSR issues & References \\
\hline CSR discussion & $\begin{array}{l}\text { Burke and Logsdon (1996) } \\
\text { Carroll (1979) } \\
\text { Clarkson (1995) } \\
\text { Freeman (1984) } \\
\text { Hopkins (2003) } \\
\text { Jones (2003) } \\
\text { Lantos (2001) } \\
\text { van Luijk (1999, 2005) } \\
\text { Mintzberg (1983) } \\
\text { Moore (2003) } \\
\text { Porter (2003) } \\
\text { Wartick and Cochran (1985) } \\
\text { Wood (1991) }\end{array}$ \\
\hline $\begin{array}{l}\text { CSR and small and } \\
\text { micro companies }\end{array}$ & $\begin{array}{l}\text { Grayson (2004) } \\
\text { Spence (1999) } \\
\text { Spence et al. (2000) } \\
\text { Spence et al. (2003) } \\
\text { Spence and Lozano (2000) } \\
\text { Spence and Rutherfoord (2003) } \\
\text { Spence and Schmidpeter (2003) } \\
\text { Thompson and Smith (1991) } \\
\text { Tilley (2000) } \\
\text { Vyakarnam et al. (1997) }\end{array}$ \\
\hline $\begin{array}{l}\text { The business case of } \\
\text { CSR: CSR and } \\
\text { competitiveness }\end{array}$ & $\begin{array}{l}\text { Allouche and Laroche (2005) } \\
\text { Barney (1991) } \\
\text { De Bakker et al. (2005) } \\
\text { Epstein and Roy (2001) } \\
\text { European Competitiveness Report } \\
\quad \text { (2008) } \\
\text { Frooman (1997) } \\
\text { Kay (1993) } \\
\text { Kong et al. (2002) } \\
\text { Hamel and Prahalad (1989) } \\
\text { Hansen (2004) } \\
\text { Heal (2005) } \\
\text { Lowell (2007) } \\
\text { Margolis et al. (2007) } \\
\text { Mintzberg (1993) } \\
\text { Murths and Lenway (1998) } \\
\text { Orlitzky (2005) } \\
\text { Orlitzky et al. (2003) } \\
\text { Orlitzky and Benjamin (2001) } \\
\text { Podolny (1993) } \\
\text { Porter (1985) } \\
\text { Porter and van der Linde (1998) } \\
\text { Rondinelli and London (2002) } \\
\text { Schaltegger and Burritt (2005) } \\
\text { Schreck (2011) } \\
\text { Stuebs and Sun (2010) }\end{array}$ \\
\hline
\end{tabular}

Table 2 continued

\begin{tabular}{ll}
\hline CSR issues & References \\
\hline Stuebs and Sun (2009) \\
Turban and Greening (1997) \\
Vilanova et al. (2009) \\
Waddock and Graves (1997) \\
Weber (2008) \\
Wood (2010) \\
Wu (2006) \\
Porter (1985) \\
Vilanova et al. (2009) \\
As a dimension of \\
competitiveness \\
productivity
\end{tabular}

Source author-compiled data

This table is only for guidance and does not aim to be exhaustive

The model identifies diverse competitiveness dimensions as follows: (1) financial performance, (2) quality, (3) efficiency and productivity, (4) innovation and (5) image.

Following Stuebs and Sun (2010), the model incorporates business reputation as an important driver to initiate CSR activities. According to Schreck (2011), CSR dimensions are also related to competitiveness through different mediators which are grouped together in the following way: (1) improvement in operating processes, (2) cost savings, (3) attracting and retaining the employee, (4) employee motivation, (5) access to credit and capital markets, (6) innovation and (7) risk management.

Few studies have analysed the relationship between CSR and labour productivity. This paper focuses on this relationship, considering labour productivity as an element of competitiveness, and the dimensions that are most relevant to the case of CSR, by analysing the mediating variables that interact with labour productivity.

Regarding the CSR dimensions considered, this article mainly focuses on the dimensions of the relationship with the community, relationship with employees, the environment and responsibility in process quality and product 
Fig. 1 Effects of CSR policies on competitiveness adapted to small companies. Source

Modified CSR and

competitiveness framework.

Schreck (2011), Stuebs and Sun (2010), and Vilanova

et al (2009)

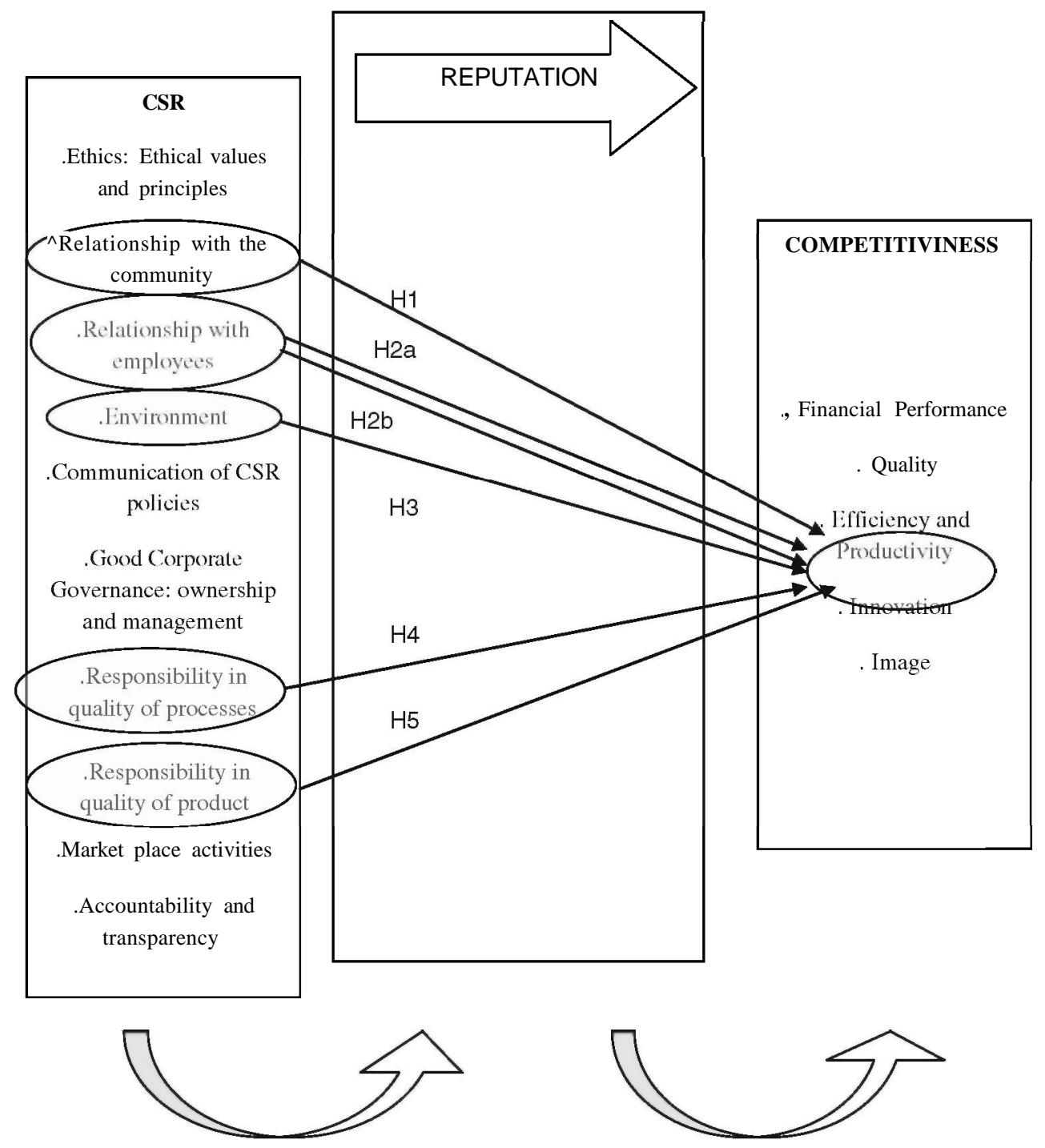

quality. The objective is to link these dimensions to labour productivity through the chosen mediators or variables for a representative sample of small and micro Spanish companies in the industrial manufacturing sector.

This work studies the relationship between CSR and labour productivity from the perspective of several dimensions of CSR by taking into account different mediating variables.

\section{Main Hypotheses}

All the hypotheses were tested for two different samples: (a) small and micro companies and (b) micro companies to test for differences between micro and small companies.

The good relationship with the community and other external stakeholders can be turned into a competitive advantage by improving employee motivation and boosting productivity (Porter and Kramer 2002). A good relationship with external stakeholders helps build trust, loyalty and confidence among consumers, managers and employees alike, and can also improve image and brand reputation. These arguments lead us to these hypotheses:

$\mathrm{Hx}$ There is positive link between labour productivity and a small or micro company's relationship with the community and external stakeholders.

The effects of a company's relationship with the community and external stakeholders can be seen more in the long term, but small- and medium-sized enterprises (SMEs) often lack the long-term strategic vision of large firms. Therefore, they are less willing to develop long-term strategic relationships with stakeholders (Lee 2008).

Good relations with employees can boost labour productivity. When employees are beneficiaries of CSR actions, their satisfaction can increase. Furthermore, companies that are well known for having a good relationship 
with the workforce can attract and retain more highly qualified people and reduce employee turnover (Albinger and Freeman 2000; Greening and Turban 2000). This, in turn, has positive effects on a company's operational efficiency (Branco and Rodriguez 2006) and brings labour resource efficiency advantages (Fombrun 1996; Podolny 1993).

However, the relationship between these advantages and labour costs is not clear. Some authors consider that companies with good CSR policies and high reputations may decide to pay higher wages to employees to maintain satisfaction (Stuebs and Sun 2010), while others consider that workers are willing to receive less compensation to work in a company with good CSR policies and reputation (Podolny 1993; Roberts and Dowling 2002).

All of this also holds for SMEs in Italy (Longo et al. 2005), the UK (Toyne 2003; Jenkins 2006) and Denmark (Kramer et al. 2007). Consequently, the hypothesized changes in terms of lower labour costs and higher labour productivity should result in increased labour efficiency (Stuebs and Sun 2010).

This study measures good relations with employees through two variables: training expenditure per employee and labour costs as a percentage of sales as a proxy of sales value distribution to employee. The sales value distribution to employee (labour costs as a percentage of sales) is measured as the inverse of labour efficiency (Eq. 5) as follows:

Sales value distribution to employee

$=\frac{\text { Total Labour costs }}{\text { Sales }}$.

A negative relationship between labour productivity and Eq. 6 would indicate a positive relationship between labour productivity and labour efficiency according to Stuebs and Sun (2010). This suggests that increases in labour costs may reduce labour productivity and labour efficiency. This paper aims to show the need to relate the CSR policy of 'good relations with employees' to increases in productivity to achieve improvements in labour efficiency and preserve the positive effects than can be derived from this CSR policy. This study defends the idea that better salaries should be related to significant increases in productivity, even from a CSR perspective. With this in mind, the second group of hypotheses is formulated as follows:

$\mathrm{H}_{2 \mathrm{a}}$ There is a negative link between labour productivity and a small and micro company's relationship with labour costs as a percentage of sales (sales value distribution to employee).

$\mathrm{H}_{2} \mathrm{~b}$ There is a positive link between labour productivity and a small and micro company's training expenditure.
Academic studies on the cost-saving effects of the environmental dimension of CSR have obtained mixed results. Environmental expenditure constitutes environmental investments that pay off because of cost savings as a result of lower insurance, lower energy costs or reductions in waste (Miles and Covin 2000). However, in the short term, environmental investments can also lead to significant costs associated with waste reduction practices, especially in manufacturing industries (Chappie et al. 2005). Thus, it is difficult to draw a general conclusion about the cost-saving effects of environmental investments. Prior studies have shown evidence of both positive and negative relationships between CSR and cost structure (European Commission 2008). The effects may be produced more in the long term, but as SMEs often lack the long-term strategic vision of large companies, they are less willing to make environmental investments. They may lack the resources to show leadership in environmental performance (Lee 2008). Therefore, we hypothesize the following:

$\mathrm{H}_{3}$ Environmental expenditure has no relevant relationship with labour productivity in small and micro companies.

Proponents of CSR have tended to argue that CSR can lead to cost savings, while critics argue that CSR is expensive and that benefits are often visible only in the long term (European Commission 2008). Although there are examples of cost structure improvements due to CSR measures (Woodward et al. 2001), there is also evidence of how the cost-benefit relationship of CSR measures can be negative in certain circumstances. Welford (2003) argued that only a few CSR measures might reduce costs, and these measures can be related to improved efficiency in operational processes and quality controls. As a result, the following hypothesis is formulated:

$\mathrm{H}_{4}$ There is a positive relationship between labour productivity and a small and micro company's quality control of operational processes.

Some scholars have argued that CSR can be a route to innovation thanks to the use of CSR drivers, such as social, quality or environmental challenges, to create new and more efficient ways of working, processes or products (Grayson and Hodges 2004). Through the analysis of innovative Italian, Spanish and English SMEs, Mendibil et al. (2007) showed how innovation performance and CSR are positively linked, even if the cause and effect relationship is not entirely clear.

There could be three main sources of a positive relationship between CSR and innovation: stakeholder engagement, business opportunities through societal and environmental challenges, and efforts to create workplaces 
that are more conducive to innovation (European Commission 2008).

Mendibil et al. (2007) also described how innovation and CSR come together in a case study of Spanish SMEs in the industrial tool manufacturing sector. Strong engagement between employees and external stakeholders contributes to the innovativeness and competitiveness model of companies.

The European Competitiveness Report (European Commission 2008, p. 112) suggests that 'CSR involves creating better workplaces, which can be more conducive to innovation [...] Working conditions and the treatment of employees are determinant factors.' The European Commission in its 2006 Communication on innovation policy states, 'Innovation needs to be organised in a way that supports not only the acceptance of change, but also provides opportunities in human resource management, leading to higher productivity' (European Commission 2006). Accordingly, the last hypothesis is formulated as follows:

$\mathrm{H}_{5}$ There is a positive relationship between labour productivity and small and micro companies' R\&D expenditure as a percentage of sales.

\section{Data Analysis and Methodology}

\section{Sample and Data Collection}

This study gathered data from the Survey on Business Strategies (ESEE). The ESEE began in 1990 thanks to an agreement between the Spanish Ministry of Science and Technology (at the time, the Ministry of Industry and Energy) and the Spanish SEPI Foundation, which was responsible for its design and control through the Program for Economic Research.

The ESEE is a statistical survey that collects data from an annual business survey sent to a panel of Spanish manufacturing companies and includes various aspects related to their strategic behaviour and decision making. It also includes information about their results and account balances. The sample is representative of the Spanish manufacturing sector. Although this source of information contains data from 1990 on, this paper concentrates on the years 2009-2010. One of the common characteristics of the dataset is that firms participating in the questionnaire are selected according to a selective sampling method. The sample comprises companies that have between 1 and 49 employees. Table 2 shows the technical data from the study. The proposed model was analysed for two different samples. The first one included small companies and the second one considered micro companies. The aim was
Table 3 Technical data from the study

\begin{tabular}{ll}
\hline $\begin{array}{l}\text { Population } \\
\text { Unit }\end{array}$ & Spanish manufacturing sector \\
Questionnaire design & SEPI Foundation \\
Population types & More than 100,000 elements \\
Time period & Data from 2009 to 2010 \\
Sampling & \\
Type of sampling & Random stratified census according \\
& to activity, sector and firm size \\
Sample size & Sample $1: 929$ small Spanish \\
& manufacturing firms; Sample 2: \\
& 135 Spanish microenterprises \\
Sampling error (approx.) & $0.028(p=q=0.50)$ \\
Level of confidence & $95 \%(K=2 a)$ \\
Data treatment & Statistical Solutions for Products \\
& and Services (SPSS) \\
\hline
\end{tabular}

Source author-compiled data

detect differences in behaviour between small and micro companies (Table 3).

Variables and Measurements

\section{Dependant Variables}

Traditionally, there has always been controversy over the choice of variables that represent the required input and output for the calculation of productivity (PROD). Thus, we chose a double analysis, measuring this variable using two different ratios. Following the lines of studies such as the one by Sauian (2002), Eq. 3b defines labour productivity (PE) as the quotient of a company's total production and its average number of employees.

Total production is measured as the value of production of goods and services in thousands of euros, calculated as total sales plus the value of changes in stock.

In Eq. 3a, however, labour productivity (SA) is measured based on the earnings obtained by the company from total sales. Stuebs and Sun (2010) calculate labour productivity not only through the quotient of income before labour costs and number of employees but they also use the quotient of earnings from total sales and number of employees, obtaining regression results and analyses qualitatively similar for both labour productivity measures.

\section{Independent Variables}

This work has broken the independent variables down into the different CSR policies undertaken by small companies in the areas of performance which are more accessible to them, bearing in mind their limited size and resources. According to the different dimensions mentioned in the 
Table 4 CSR dimensions and independent variables

\begin{tabular}{|c|c|c|}
\hline CSR dimensions & Independent variables & Hypothesis \\
\hline $\begin{array}{l}\text { 1. Relationships } \\
\text { with the } \\
\text { community }\end{array}$ & $\begin{array}{l}\text { 1. Innovation of external } \\
\text { relationships }\end{array}$ & $\wedge$ \\
\hline \multirow[t]{2}{*}{$\begin{array}{l}\text { 2. Relationships } \\
\text { with employees }\end{array}$} & $\begin{array}{l}\text { 2. Sales value distribution to } \\
\text { employees }\end{array}$ & $H 2 a$ \\
\hline & 3. Employee training & $\mathrm{H}_{2} b$ \\
\hline 3. Environment & 4. Environmental protection & H3 \\
\hline $\begin{array}{l}\text { 4. Responsibility in } \\
\text { processes }\end{array}$ & $\begin{array}{l}\text { 5. Improving the quality of } \\
\text { processes and services }\end{array}$ & H4 \\
\hline $\begin{array}{l}\text { 5. Responsibility in } \\
\text { product quality }\end{array}$ & $\begin{array}{l}\text { 6. Innovation and improvement } \\
\text { of processes and products }\end{array}$ & H5 \\
\hline
\end{tabular}

Source author-compiled data

theoretical model and adapting them to the small company, the following independent variables have been defined, each representing one of the dimensions of CSR that can be undertaken by small companies (Table 4).

This work follows the lines of studies such as that by Schreck (2011), in which different variables are defined according to CSR policies to analyse the effect that they produce on the dependent variable. Other studies have used these variables, but in a combined index, like the Fortune's America's Most Admired Companies (Stuebs and Sun 2010). Previous studies have included the CSR variable divided into ethical, legal, economic and environmental dimensions (Marin Rives and Rubio Banon 2008), while others studies have focused on only one of these dimensions, such as the environmental dimension (Williamson et al. 2006).

\section{Control Variables}

As Schreck (2011) pointed out, there is no universal business case for CSR. He considered the different industry classes and the quality of a company's CSR report as moderators or control variables as examples of contingencies that could influence the relationship between social and financial performance. In linear regression analyses, there can be other moderators or control variables modelled in terms of interaction (Jaccard and Turrisi 2003) such as company size, degree of internationalization or company age among others (Schreck 2011).

This study considered the following control variables: identification of owner managers, geographical concentration and degree of absenteeism. It only considered three variables to mitigate the risk of small sample sizes and prevent the miscalculation of regression coefficients.

The presence of owner managers can be relevant in micro and small companies because founders may be more identified with ethical principles and CSR values. The founders' commitment to CSR principles can strengthen the mediating effects on competitiveness, as they do not adopt CSR policies for image or reputation purposes alone. Their CSR policies are more linked to the owner's ethical principles and values and are therefore more credible to stakeholders (Vicente Molina et al. 2004). Consequently, owner managers can allocate resources to CSR policies with more flexibility according to their own criteria (Spence and Rutherfoord 2001). The greater proximity to the closest interest groups and the greater identification of RSE policies with the owner's values, in turn, generate greater credibility when communicating the policies and actions carried out by the micro company in the area of CSR to the outside world. For SMEs, the ethics of owner managers can play a much greater role in engaging CSR than in a large company (Lee 2008). Therefore, this control variable is expected to have a positive relationship with the dependent variables explained in the two models.

With regard to the second control variable which refers to geographical concentration, the local or regional geographical area where small and micro companies frequently operate, as opposed to large companies, strengthens the effects on labour productivity (Rice and Venables 2004; Ciccone 2002). Companies, far from spreading themselves out at regular distances, tend to concentrate in small geographical areas to take advantage of cross-sector relationships or the proximity of a very specialised labour market and share sources of information more efficiently. Benefits are gained from (a) the flow of information among the different companies that make up the sector; (b) cross-sector relationships between suppliers and manufacturers of finished goods; and (c) proximity to a highly specialised labour market (Mate Sanchez-Val et al. 2009).

Thus, company location can be considered a source of competitive advantage, which companies should take into account when setting up a business (Viladecans and Costa 1999; Taymaz 2002). In this respect, there are two schools of thought: The New Theory of Growth and the Theory of Localization (Callejon 2002). These theories consider spatial concentration, the local or regional character of the small company, to be a growth factor that may stimulate other factors of production (Baumont 1997), such as the labour factor which can affect labour productivity. Thus, we can expect there to be a positive relationship with the variable explained in the two models.

Absenteeism in the workplace has been included as the third variable, as it is expected to moderate the effect of CSR on competitiveness. The effect should, therefore, be dependent on the company's level of absenteeism. High levels of absenteeism can moderate the positive effect of CSR policies on labour productivity. Greater absenteeism is expected to result in greater inefficiencies, lowering labour productivity rates (Miller et al. 2008; Garcia 
Table 5 Variables of proposed models

\begin{tabular}{|c|c|c|c|c|c|c|}
\hline Variable type & Study variables & Variable to analyse & Definition & $\begin{array}{l}\text { Name } \\
\text { (hypothesis) }\end{array}$ & Source & Values and year of data \\
\hline \multirow{2}{*}{$\begin{array}{l}\text { Dependent: } \\
\text { Labour } \\
\text { productivity } \\
\text { (PROD) }\end{array}$} & $\begin{array}{l}\text { Productivity per } \\
\text { employee }\end{array}$ & Production per employee & $\begin{array}{l}\text { Value of production of goods and services in } \\
\text { thousands of euros, divided by the average total } \\
\text { staff }\end{array}$ & PE & $\begin{array}{l}\text { Data from the } \\
\text { Survey on } \\
\text { Business }\end{array}$ & $\begin{array}{l}\text { Continuous } \\
(2010)\end{array}$ \\
\hline & Sales per employee & Sales per employee & $\begin{array}{l}\text { Euro value of sales of the company by the total } \\
\text { number of workers }\end{array}$ & SA & Strategies & $\begin{array}{l}\text { Continuous } \\
(2010)\end{array}$ \\
\hline \multirow[t]{6}{*}{ Independent } & Policies of CSR & $\begin{array}{l}\text { Innovation of external } \\
\text { relationships }\end{array}$ & $\begin{array}{l}\text { Indicates whether the company introduced new } \\
\text { organisational methods, related to new } \\
\text { methods of management of external } \\
\text { relationships with other companies or public } \\
\text { institutions }\end{array}$ & $\begin{array}{l}\text { EXT } \\
\text { (Hi) }\end{array}$ & & $\begin{array}{l}0=\text { No } \\
1=\text { Yes } \\
(2009)\end{array}$ \\
\hline & & $\begin{array}{l}\text { Sales value distribution to } \\
\text { employees }\end{array}$ & Labour costs as a percentage of sales & $\begin{array}{l}\text { VAL } \\
\left(\mathrm{H}_{2 \mathrm{a}}\right)\end{array}$ & & $\begin{array}{l}\text { Continuous } \\
\text { (labour cost/sales) } \\
(2009)\end{array}$ \\
\hline & & Training for employees & $\begin{array}{l}\text { Total expenditure on external training for } \\
\text { workers on the approximation of the average } \\
\text { total. Expressed in Euros per employee }\end{array}$ & $\begin{array}{l}\text { TRAI } \\
\left(\mathrm{H}_{2} \mathrm{~b}\right)\end{array}$ & & $\begin{array}{l}\text { Continuous } \\
\text { Total expenditure } \\
(2009)\end{array}$ \\
\hline & & Environmental protection & Expenditures on environmental protection & GEN $\left(\mathrm{H}_{3}\right)$ & & $\begin{array}{l}1=\text { Yes } \\
2=\text { No } \\
(2009)\end{array}$ \\
\hline & & $\begin{array}{l}\text { Improving the quality of } \\
\text { processes and services }\end{array}$ & $\begin{array}{l}\text { Indicates whether the firm has conducted or } \\
\text { contracted standardization and quality control }\end{array}$ & QUAdT, ) & & $\begin{array}{l}0=\text { No } \\
1=\text { Yes } \\
(2009)\end{array}$ \\
\hline & & $\begin{array}{l}\text { Innovation and } \\
\text { improvement of processes } \\
\text { and products }\end{array}$ & $\begin{array}{l}\text { Percentage of total R\&D expenditure on sales } \\
\text { volume }\end{array}$ & $\begin{array}{l}\text { INN } \\
\left(\mathrm{H}_{\mathrm{s}}\right)\end{array}$ & & $\begin{array}{l}0=0 \% \\
1=\text { from } 0 \text { to } 1 \% \\
2=\text { from } 1 \text { to } 2.5 \% \\
3=\text { from } 2.5 \text { to } 5 \% \\
4=\text { from } 5 \text { to } 10 \% \\
5=\text { more than } 10 \% \\
(2009)\end{array}$ \\
\hline Control & $\begin{array}{r}\text { Control and } \\
\text { ownership }\end{array}$ & $\begin{array}{l}\text { Coincidence of ownership } \\
\text { and control }\end{array}$ & $\begin{array}{l}\text { Indicates whether there is a coincidence of } \\
\text { ownership and control of the company }\end{array}$ & ID & & $\begin{array}{l}0=\text { No } \\
1=\text { Yes } \\
(2009)\end{array}$ \\
\hline
\end{tabular}


Olaverry and Huertas 2012; Chatterji and Tilley 2002). In this case, a negative relationship with the dependent variable in the two models is expected.

Table 5 describes the variables that make up the model. Data on the dependent variables are from 2010, while data on the other variables are from 2009. The objective was to determine the effect of CSR policies on a company's labour productivity. As this effect is not immediate, data on labour productivity were used from 1 year later.

\section{Analysis Methodology}

The two comparative models analyse the effects of different social responsibility policies on employees of small businesses from the standpoint of labour productivity. The first model uses production per employee as a measure of labour productivity. The second model uses sales per employee as a variable for labour productivity. Both models are tested for parallel and complementary samples. The first sample included companies with less than 49 employees (Sample 1: Small companies). The second sample included companies with less than 10 employees (Sample 2: Micro companies).

Lineal regression techniques are adequate in this case because the adjusted values of a lineal regression are not restricted to values zero and one, but both dependent variables take continuous values.

\section{Results}

The results of the descriptive statistics and correlation matrices are shown in Tables 6 and 7, respectively.

The results obtained from the regression model are presented in Table 8.

\section{Small Companies}

Table 8 shows that the results are the same for both modell $\mathrm{a}_{\mathrm{a}}$ and modellb regardless of the way that the dependent variable was measured.

The results obtained in the OLS regression show that the EXT variable was not significant. Therefore, hypothesis $\mathrm{Hi}$, which suggested a positive relationship between labour productivity and the relationship with interest groups outside the company, can be rejected. As this study analysed the short-term effects of variables, that is to say, from 1 year to the next, the obtained results indicate that the relationship with the community and external stakeholders does not have a short-term effect on labour productivity.

On the other hand, the results indicate that hypothesis $\mathrm{H} 2 \mathrm{a}$ should be accepted. Labour costs as a percentage of sales (sales value distribution to employee-VAL) have a negative relationship with labour productivity, suggesting 
Table 6 Descriptive statistics

\begin{tabular}{|c|c|c|c|c|c|c|c|c|}
\hline & \multicolumn{4}{|c|}{ Small companies $(n=929)$} & \multicolumn{4}{|c|}{ Microenterprises $(n=135)$} \\
\hline & Mean & Min & Max & SD & Mean & Min & Max & SD \\
\hline $\mathrm{PE}$ & 120.35 & 7.60 & $3,523.80$ & 154.24 & 97.78 & 9.20 & 665 & 114.13 \\
\hline SA & 120.35 & $5,107.50$ & $3,292.875$ & $153,521.6$ & $110,984.60$ & $5,107.5$ & 760,359 & $146,576.75$ \\
\hline EXT & 0.06 & 0 & 1 & 0.24 & 0.06 & 0 & 1 & 0.23 \\
\hline VAL & 0.36 & 0.1 & 1.59 & 0.20 & 0.48 & 0.04 & 1.32 & 0.24 \\
\hline TRAI & 384.46 & 0 & 50,000 & $1,986.39$ & 302.97 & 0 & 21,566 & $1,888.91$ \\
\hline GEN & 1.690 & 0 & 1 & 0.46 & 0.17 & 0 & 1 & 0.37 \\
\hline QUA & 0.26 & 0 & 1 & 0.44 & 0.13 & 0 & 1 & 0.33 \\
\hline INN & 0.31 & 0 & 5 & 0.92 & 0.02 & 0 & 5 & 0.19 \\
\hline ID & 0.71 & 0 & 1 & 0.45 & 0.91 & 0 & 1 & 0.45 \\
\hline $\mathrm{COV}$ & 3.64 & 1 & 6 & 1.42 & 2.08 & 1 & 6 & 1.36 \\
\hline ABS & 26.42 & 0 & 960 & 99.12 & 29.82 & 0 & 850 & 105.44 \\
\hline
\end{tabular}

Source author-compiled data

Table 7 Correlation matrix

\begin{tabular}{|c|c|c|c|c|c|c|c|c|c|c|c|}
\hline & PE & SA & $\mathrm{COV}$ & TRAI & INN & ID & EXT & GEN & QUA & VAL & ABS \\
\hline PE & 1 & - & & & & & & & & & \\
\hline SA & - & 1 & & & & & & & & & \\
\hline $\mathrm{COV}$ & $0.22^{*}$ & $0.21 *$ & 1 & & & & & & & & \\
\hline TRAI & 0.05 & $-0.06^{*}$ & $0.11^{*}$ & 1 & & & & & & & \\
\hline INN & $0.21 *$ & $0.08 *$ & $0.27^{*}$ & $0.25^{*}$ & 1 & & & & & & \\
\hline ID & $-0.06 *$ & $0.16^{*}$ & 0.00 & $-0.08 *$ & -0.03 & 1 & & & & & \\
\hline EXT & $0.08^{*}$ & $0.2^{*}$ & 0.02 & $0.06^{*}$ & $0.10^{*}$ & -0.02 & 1 & & & & \\
\hline GEN & $0.16^{*}$ & $-0.44 *$ & $0.08 *$ & $0.18^{*}$ & $0.17^{*}$ & 0.02 & $0.09 *$ & 1 & & & \\
\hline QUA & $0.2 *$ & $0.21 * *$ & $0.11^{*}$ & $0.16^{*}$ & $0.26^{*}$ & -0.03 & 0.05 & $0.15^{*}$ & 1 & & \\
\hline VAL & $-0.44 *$ & $-0.44 *$ & $-0.16^{*}$ & -0.04 & $-0.12 *$ & 0.00 & $-0.06^{*}$ & $-0.09 *$ & $-0.14 *$ & 1 & \\
\hline $\mathrm{ABS}$ & -0.05 & -0.05 & $0.07 *$ & $0.10^{*}$ & 0.06 & -0.02 & 0.02 & $0.10^{*}$ & 0.03 & $0.12 *$ & 1 \\
\hline
\end{tabular}

Source author-compiled data

Sample: small business

$* p<0.05$; for each pair of continuous variables, Pearson's correlation coefficient is reported, while Spearman's rank correlation coefficient is reported for nominal variables

that labour efficiency (understood to be inverse of the VAL variable shown) has a positive influence on labour productivity (Stuebs and Sun 2010). Labour productivity increases if the ratio sales/labour cost increases, yet it decreases if the ratio labour cost/sales (VAL) increase. ${ }^{2}$

2 By definition, the dependent variable (SA) (sales/employee) will have a negative relationship with the variable (VAL) (labour costs/ sales) because the numerator of the dependent variable is the denominator of the independent variable. Because labour costs and employees are highly correlated and because production and sales are highly correlated, the same is true for the dependent variable (PE). In order to prove that the statistical result is due to the underlying hypothesized $\mathrm{H} 2$ relationship and not the above-mentioned arithmetic variable definition, we tested the model with the Labour Costs variable instead of the VAL variable. The results obtained with the Labour Costs variable were also significant.
These results show that more efforts are needed to relate better salaries to significant increases in productivity, even from the perspective of CSR policies.

As the TRAI variable was not significant in the analysis, hypothesis $\mathrm{H}_{2} \mathrm{~b}$ should be rejected. These results may be due to two reasons. First, the effects of training can have a greater impact in the long term, yet be inconclusive in the short term. Secondly, small companies do not make large investments in training (average amount spent on training is 384 Euros).

As the GEN variable was not significant in the analysis, hypothesis $\mathrm{H}_{3}$ should also be rejected. Thus, expenditure on environmental protection does not have an influence on productivity in the short term. Employee enthusiasm and motivation to work for an environmentally responsible 
Table 8 OLS analysis results

\begin{tabular}{|c|c|c|c|c|c|c|c|c|c|c|}
\hline \multirow{6}{*}{$\begin{array}{l}\text { General } \\
\text { modef: } \\
\text { Variables }\end{array}$} & \multicolumn{10}{|c|}{$($ PRODit $)=\tilde{f t}+\tilde{f} t E X T i t+V_{t a L i} \wedge 2$} \\
\hline & \multirow[t]{5}{*}{ Hypotheses } & \multirow{5}{*}{$\begin{array}{l}\text { Expected } \\
\text { directions }\end{array}$} & \multicolumn{8}{|l|}{ Sample } \\
\hline & & & \multicolumn{4}{|c|}{ Small business $(n=929))$} & \multicolumn{4}{|c|}{ Microenterprises $(n=135)$} \\
\hline & & & \multicolumn{2}{|l|}{ Model 1} & \multicolumn{2}{|l|}{$\mathrm{Model}_{2}$} & \multicolumn{2}{|l|}{ Model 1} & \multicolumn{2}{|l|}{ Model $_{2} \mathrm{~b}$} \\
\hline & & & \multicolumn{2}{|l|}{$\mathrm{PEi}$, } & \multicolumn{2}{|l|}{ SAit } & \multicolumn{2}{|l|}{ PEit } & \multicolumn{2}{|l|}{ SAit } \\
\hline & & & Coef (SE) & T-stat & Coef. (SE) & T-stat & Coef. (SE) & T-stat & Coef. (SE) & T-stat \\
\hline Const. & & & $\begin{array}{l}223.42 \\
(17.91)\end{array}$ & 5.592 & $\begin{array}{l}214,112.13 \\
(17,805.13)\end{array}$ & 5.247 & $\begin{array}{l}213.87 \\
(30.51)\end{array}$ & 2.741 & $\begin{array}{l}229,227.09 \\
(41,781.10)\end{array}$ & 1.613 \\
\hline EXT & $\mathrm{Hi}$ & + & $\begin{array}{l}5.19 \\
(18.37)\end{array}$ & 0.312 & $-33,976.21 \quad(9,803.84)$ & -0.054 & $\begin{array}{l}9.90 \\
(34.68)\end{array}$ & 0.138 & $\begin{array}{l}-19,168.93 \\
(47,495.93)\end{array}$ & -0.477 \\
\hline VAL & $\mathrm{H}_{2} \mathrm{a}$ & $"$ & $\begin{array}{l}\mathbf{- 3 1 1 . 4 5 * " <} \\
(22.37)\end{array}$ & -13.897 & $\begin{array}{l}\mathbf{- 3 5 , 4 9 9 . 6 9 * * *} \\
(10,521.31)\end{array}$ & -13.733 & $\begin{array}{l}\mathbf{- 2 3 9 . 1 0 * * *} \\
(33.69)\end{array}$ & -7.213 & $\begin{array}{l}\mathbf{- 2 7 8 , 5 1 2 . 7 2} * * * \\
(46,131.61)\end{array}$ & -6.114 \\
\hline TRAI & $\mathrm{H} 2 \mathrm{~b}$ & + & $\begin{array}{l}0.003 \\
(0.002)\end{array}$ & 0.168 & $\begin{array}{l}2.02 \\
(2.26)\end{array}$ & 0.358 & $\begin{array}{l}0.003 \\
(0.004)\end{array}$ & 1.087 & $\begin{array}{l}2.41 \\
(5.91)\end{array}$ & 0.643 \\
\hline GEN & H3 & - & $\begin{array}{l}-0.29 \\
(9.97)\end{array}$ & -0.002 & $-442.25 \quad(18,267.33)$ & -0.150 & $\begin{array}{l}-2.04 \\
(21.52)\end{array}$ & -0.055 & $\begin{array}{l}-1,799.31 \\
(29,464.91)\end{array}$ & -0.074 \\
\hline QUA & $\mathrm{H}_{4}$ & + & $\begin{array}{l}\text { 36.11*** } \\
(10.58)\end{array}$ & 3.422 & $\begin{array}{l}\mathbf{1 , 2 5 4 . 0 9 * * *} \\
(9,910.89)\end{array}$ & 3.382 & $\begin{array}{l}\mathbf{8 1 . 1 8}^{* * *} \\
(25.29)\end{array}$ & 3.038 & $\begin{array}{l}\mathbf{7 9 , 0 0 8 . 5 2} \% * * \\
(34,638.44)\end{array}$ & 2.209 \\
\hline INN & H3 & + & $\begin{array}{l}0.73 \\
(5.17)\end{array}$ & 0.239 & $\begin{array}{l}11.80 \\
(45.32)\end{array}$ & 0.398 & $\begin{array}{l}\text { 94.50*** } \\
(42.10)\end{array}$ & 2.285 & $\begin{array}{l}\mathbf{1 1 4 , 9 8 1 . 6 8} * * * \\
(57,651.80)\end{array}$ & 2.040 \\
\hline ID & & $"$ & $\begin{array}{l}0.73 * * * \\
(5.17)\end{array}$ & 3.624 & $\begin{array}{l}\mathbf{1 , 6 0 5 . 4 9} \text { **** } \\
(5,139.50)\end{array}$ & 3.503 & $\begin{array}{l}-0.67 \\
(18.25)\end{array}$ & -0.048 & $\begin{array}{l}-13,955.81 \\
(24,992.21)\end{array}$ & -0.607 \\
\hline $\mathrm{COV}$ & & + & $\begin{array}{l}7.06 * * * \\
(3.31)\end{array}$ & 2.207 & $\begin{array}{l}\mathbf{9 , 5 5 4 . 2 1} * * * \\
(3,299.58)\end{array}$ & 2.965 & $\begin{array}{l}-4.04 \\
(5.98)\end{array}$ & -0.597 & $\begin{array}{l}4,802.04 \\
(8,192.552)\end{array}$ & 0.569 \\
\hline ABS & & - & $\begin{array}{l}-0.009 \\
(0.046)\end{array}$ & -0.202 & $\begin{array}{l}-305,700.74 \\
(22,242.96)\end{array}$ & -0.260 & $\begin{array}{l}-0.052 \\
(0.077)\end{array}$ & -0.730 & $\begin{array}{l}-24.93 \\
(104.95)\end{array}$ & -0.375 \\
\hline \multicolumn{3}{|l|}{$\stackrel{R 2}{\Omega}$} & 022 & & 022 & & 0.344 & & 0.255 & \\
\hline \multicolumn{2}{|c|}{ Durbin Watson } & & 1.9 & & 1.9 & & 2.1 & & 2 & \\
\hline
\end{tabular}

Source author-compiled data

$* p<0.1 ; * * p<0.05 ; * * * p<0.01$

a The definition of each variable can be seen in Table 5

company do not make companies more productive in the short term.

Hypothesis $\mathrm{H}_{4}$, however, should be accepted, given that the variable that represents the company's concern for the quality of its processes and products (QUA) did have an influence on productivity. Both improvement in processes (with the aim of increasing production efficiency) and improvement in products (to increase sales) had a significant positive effect on productivity.

Lastly, hypothesis $\mathrm{H}_{5}$, which refers to the involvement of a company in innovation in terms of both products and processes, should be rejected. As the INN variable did not appear to be significant, innovation does not seem to have a positive effect on labour productivity in small companies in the short term. Innovation tends to be a process that generally has results in the medium term, and small companies have difficulty committing themselves to processes and investments that have an expected long-term trajectory (Tödtling and Kaufmann 2001).

With regard to the control variables, both the identity between ownership and control (ID) and the index for concentration of companies (COV) had a significant positive influence on worker productivity, as expected. Absenteeism in the workplace (ABS) was not significant, but the sign preceding it showed that it had a negative effect on worker productivity, as expected.

\section{Micro Companies}

The results obtained from the OLS regression for the sample of micro companies indicate that hypotheses $\mathrm{Hi}, \mathrm{H}_{2} \mathrm{~b}, \mathrm{H}_{3}$ and H5 should be rejected, as found for small companies.

Similarly, the significant results obtained for the variables VAL and QUA indicate that hypotheses $\mathrm{H}_{2 \mathrm{a}}$ and $\mathrm{H}_{4}$ 
should be accepted, as in the case of small companies. However, another variable was also significant: Innovation (INN). This could be due to two reasons:

- Rotation of tasks: traditionally workers in micro companies have been rotated frequently, as opposed to the specialisation found in larger-sized companies. This could favour worker participation in the innovative process, while being an incentive on a day-to-day basis. As the number of employees increases, this rotation decreases, and this effect may disappear.

- Innovation in micro companies normally refers to incremental rather than radical innovations, with an implementation time in the short term (Del Brio and Junquera 2003). As companies become bigger, innovations tend to have a longer-term effect, which is not addressed in this study (Todtling and Kaufmann 2001).

On the other hand, control variable ID did not produce significant results. In the majority of the micro companies in the sample, ownership and control coincide (average value of 0.91 for the variable was higher than in the case of small companies). Likewise, the variable COV did not provide much information in this model (thus its lack of significance). As the majority of micro companies work within a local area, the average value for this variable was lower than for small companies. As in the sample of small companies, absenteeism in the workplace (ABS) was not significant. However, the sign preceding it indicates that absenteeism had a negative effect on worker productivity, as expected.

Lastly, of the two models carried out, the one with the best fit according to the results of $R^{2}$ is the model for micro companies which measured productivity through the indicator PE. This could be because this paper focuses on the industrial sector and the indicator PE is measured in terms of production rather than in terms of sales, obtaining a better fit in the model.

\section{Conclusions}

After a review of the state of the art of the relationship among CSR, competitiveness and productivity, this work considers the theoretical and methodological contributions of Vilanova et al. (2009), Stuebs and Sun (2010), and Schreck (2011) to construct the model and framework for this research.

Vilanova et al. (2009) clarified the nature of the positive relationship between CSR and the dimensions of competitiveness, among which were efficiency and productivity. Schreck (2011) analysed causality relationships between individual CSP components or mediating effects and CFP, highlighting the multidimensional nature of the CSR construct.
Stuebs and Sun (2010) modified the model proposed by Vilanova et al. (2009) and included business reputation as an important driver to initiate CSR activities. Then they linked business reputation to labour productivity as a dimension of competitiveness. They found a positive link between business reputation and labour efficiency and labour productivity.

Within this framework, this paper proposed a model to study the relationship between CSR and the competitiveness of a company through the analysis of different mediators and components of CSR and their effects on the different components of competitiveness. Its main contribution and purpose were to find empirical evidence of efforts that could enable Spanish micro and small manufacturing companies to boost their labour productivity rates through the development of some of the main pillars of their CSR policies. This study aimed to develop new approaches and sensibilities towards work from a CSR perspective, showing how internal dimensions of CSR, such as those related to relationships with employees and responsibility in process and product quality, can improve labour productivity, thus contributing to a better society.

With regards to the obtained results, this study found that the rejected hypotheses were generally related to external aspects, with a strategic component whose effect is expected in the long term. This study did not find a positive relationship between labour productivity and relationships with the community and other external stakeholders. This could be because external relationships are conceived under a long-term strategic framework, but SMEs often lack the long-term strategic vision of larger firms. Therefore, they are less willing to develop long-term strategic relationships with stakeholders (Lee 2008).

Furthermore, no positive relationship was found between labour productivity and spending on staff training. The effects of training may have a long-term effect, but they are inconclusive in the short term. The obtained results suggest the need for intensive research on the relationship between the adequacy of the training received in small and micro companies and the quantity and quality of the resources used for this training.

Environmental investment and labour productivity were not positively correlated as expected at the outset, despite the fact that some authors suggest the existence of a positive relationship between environmental management and other types of performance indicators, like a company's financial results (Schreck 2011). Companies often tackle environmental management with the hope of obtaining benefits in terms of operational efficiency and the generation of mechanisms of innovation (Dowell et al. 2000; Heal 2005; Orsato 2006; Porter and van der Linde 1995). They also expect to gain improvements in reputation (Russo and Fouts 1997; Schwaiger 2004; Sen and Bhattacharya 2001) and 
recognition from consumers who are willing to pay more for eco-friendly products (Maignan et al. 1999; McWilliams and Siegel 2000; Mohr et al. 2001; Sen and Bhattacharya 2001). However, this study did not find a positive relationship in this sense. As Lee (2008) stated, these effects may be shown more in the long term, and SMEs often lack the long-term strategic vision of large firms. They are therefore less willing to make environmental investments. They may also lack the resources to show leadership in environmental performance.

On the other hand, the results of the study confirmed the hypotheses related to internal aspects that did not have long-term implications. CSR actions derived from a commitment to quality in internal operational processes had a positive relationship with labour productivity. This suggests that such concern rather than increased costs favours operational efficiency from the point of view of increases in labour productivity.

CSR actions committed to product quality and innovation only had a significant positive relationship with productivity in the case of micro companies. This relationship may not have been significant in the case of small companies due to the fact that the effects of innovation processes require several years to be detected, as opposed to the 2 years measured in this study. However, in the case of micro companies, the process of innovation is characterised by its lack of financial and human resources and its dependence on the attitude of the entrepreneur (Benito Hernandez et al. 2012), who in most cases is also the sole manager and owner. Innovations, therefore, tend to be short term and less ambitious, generally producing incremental rather than radical changes in products, processes and organisation. This can explain why these effects are only significant and positive for micro companies.

Likewise, the negative relationship between labour productivity and increases in labour costs in proportion to sales should be carefully analysed, even using CSR criteria. These results indicate that it is necessary to relate these measures to higher increases in productivity to achieve improvements in labour efficiency and preserve the positive effects that can be derived from them. This study defends the idea that there is still a need to relate better salaries to significant increases in productivity, even from a CSR perspective.

In conclusion, the internal dimensions of CSR, that is those related to policies that have an influence on the employee and the improvement of processes, innovation and products, contribute most to increases in labour productivity at the expense of policies related to agents external to the company, whose effects are more long term and have not been proven in this paper. This research shows how internal dimensions of CSR can improve labour performance and labour efficiency contributing to a better society, developing a new approach to work efficiency from a CSR framework.

The time limits of this study should be highlighted, as only a 1-year delay was considered in the case of some of the variables. Therefore, an interesting area of future research would be to analyse data from a longer time period. This would obtain relevant conclusions concerning CSR actions that have strategic implications and positive effects on companies' competitiveness in the long term.

Likewise, the theoretical framework of the proposed model could be of use in the study of the relationship between other components of competitiveness and their corresponding mediators. This could explain their relationship with the different dimensions of CSR, as for example, studying the relationship between innovation and the dimensions of CSR through the analysis of the different mediators of this relationship.

Finally, the negative relationship between labour productivity and labour costs as a percentage of sales (sales value distribution to employee-VAL) could be influenced by the arithmetic relationship between the numerator of the dependent variable (SA) and the denominator of the independent variable (VAL). Due to data limitations, 'Sales' was used in both cases, but in future research it could be replaced by 'Income before labour costs' or 'Net Income' variables.

\section{References}

Albinger, H. S., \& Freeman, S. J. (2000). Corporate social performance and attractiveness as an employer to different job seeking populations. Journal of Business Ethics, 28(3), 243-253.

Allouche, J., \& Laroche, P. (2005). A meta-analytical investigation of the relationship between corporate social and financial performance. Revue De Gestion Des Ressources Humaines, 57, 18^-0.

Axelrod, R. (1984). The evolution of cooperation. New York: Basic Books.

Axelrod, R., \& Cohen, M. D. (1999). Harnessing complexity. New York: Free Press.

Barney, J. (1991). Firm resources and sustained competitive advantage. Journal of Management, 17(1), 99-120.

Barney, J. B., \& Hansen, M. H. (1994). Trustworthiness as a source of competitive advantage. Strategic Management Journal, 15, 175-190.

Baumont, C. (1997). Croissance endogène et espace. In F. Céliméne \& C. Lacour (Eds.), L'intégration régionale des espace (pp. 33-61). Paris: Economica.

Becchetti, L., \& Trovato, G. (2011). Corporate social responsibility and firm efficiency: A latent class stochastic frontier analysis. Journal of Productivity Analysis, 56(3), 231.

Benito-Hernández, S., Platero Jaime, M., \& Rodriguez Duarte, A. (2012). Determinants of innovation in Spanish microenterprises: The importance of internal factors. Universia Business Review, $1,104-121$.

Bowen, H. R. (1953). Social responsibilities of the businessman. New York: Harper \& Row. 
Branco, M. C, \& Rodriguez, L. L. (2006). Corporate social responsibility and resource-based perspectives. Journal of Business Ethics, 69(2), 111-132.

Burke, L., \& Logsdon, J. M. (1996). How corporate social responsibility pays off. Longe Range Planning, 29(4), 495-502.

Callejón, M. (2002). Implicaciones de las nuevas teorias del crecimiento y la localizatión en las politicas regionales y locales. Capitulo del libro electronico: La Politico Económica en un Mundo de Incertidumbre. V Jornadas de Politico Económica. General Media. S.L. Bilbao.

Carroll, A. B. (1979). A three-dimensional conceptual model of corporate performance. Academy of Management Journal, 4(4), 497-505.

Chappie, W., Morrison Paul, C. J., \& Harris, R. (2005). Manufacturing and corporate environmental responsibility: Cost implications of voluntary waste minimisation. Structural Change and Economic Dynamics, 16, 347-373.

Chatterji, M., \& Tilley, C. J. (2002). Sickness, absenteeism, 'presenteeism' and sick pay. Oxford Economic Papers, 54(4), 669-687.

Ciccone, A. (2002). Agglomeration effects in Europe. European Economic Review, 46, 213-227.

Clarkson, M. B. E. (1995). A stakeholder framework for analyzing and evaluating corporate social performance. Academy of Management Review, 20(1), 92-117.

Commission of the European Communities. (2001). Green paper. Promoting a European frameworkfor corporate social responsibility, COM 2001 (pp. 366-end), 18.07.2001. Brussels: Commission of the European Community. Accessed March 10, 2010, from http://eur-lex.europa.eu/LexUriServ/LexUriServ.do?uri= COM:2001:0366:FIN:ES:PDF.

de Bakker, F. G., Groenewegen, P., \& Den Hond, F. (2005). A bibliometric analysis of 30 years of research and theory on corporate social responsibility and corporate social performance. Business \& Society, 44(3), 283-317.

De Schutter, O. (2008). Corporate social responsibility European style. European Law Journal, 14, 203-236.

Del Brio, J. A., \& Junquera, B. (2003). A review of the literature on environmental innovation management in SMEs: Implications for public policies. Technovation, 23(12), 939-948.

Dowell, G., Stuart, H, \& Bernard, Y. (2000) Do Corporate Environmental Standards Create or Destroy Market Value? Management Science, 46, 1059-1074.

Epstein, M. J., \& Roy, M. J. (2001). Sustainability in action: Identifying and measuring the key performance drivers. Long Range Planning, 34(5), 585-604.

European Commission. (2003). Recommendation 2003/361/CE. Accessed May 19, 2012, from http://eur-lex.europa.eu/LexUr iServ/LexUriServ.do?uri=OJ:L:2003:124:0036:0041:es:PDF.

European Commission. (2006). Implementing the partnership for growth and jobs: Making Europe a pole of excellence on corporate social responsibility. COM 136. Brussels: European Commission.

European Commission. (2008). European competitiveness report. Accessed May 12, 2012, from http://ec.europa.eu/ENTER PRISE/newsroom/cf/_getdocument.cfm?doc_id=4058.

European Commission. (2010). European competitiveness report (pp. 22-23). Accessed May 10, 2012, from http://bookshop.europa. eu/en/european-competiti venes s-report-2010-pbNB AK10001/.

European Commission, DG-ENTERPRISE. (2011). Annual report on EU small and medium sized enterprises 2010/2011. Accessed March 1, 2012, from http://ec.europa.eu/ENTERPRISE/policies/ sme/facts-figures-analysis/performance-re view/pdf/20102011/ are_the_eus_smes_recovering.pdf

Fombrun, C. (1996). Reputation: Realizing valuefrom the corporate image. Boston: Harvard Business School Press.
Freeman, R. E. (1984). Strategic management: A stakeholder approach. Boston/London: Pitman/Ballinger.

Frooman, J. (1997). Socially irresponsible and illegal behaviour and shareholder wealth. Business and Society, 36, 221-249.

Garcia Olaverry, M. C, \& Huertas, E. (2012). Infiuencia sindical en la empresa industrial espanola. Revista International del trabajo, $130\left(3^{\wedge}\right), \quad 303-322$.

Grayson, D. (2004). How CSR contribute to the competitiveness of Europe in a more sustainable world. In The World Bank Institute and the CSR Resource Centre (Netherlands) (pp. 1-5).

Grayson, D., \& Hodges, A. (2004). Corporate social opportunity! Seven steps to make corporate social responsibility work for your business. Sheffield: Greenleaf Publishing.

Greening, D. W., \& Turban, D. B. (2000). Corporate social performance as a competitive advantage in attracting a quality workforce. Business and Society, 39(3), 254-280.

Hamel, G., \& Prahalad, C. K. (1989). Strategic intent. Harvard Business Review, 3, 63-76.

Hansen, U. (2004). Gesellschaftliche Verantwortung als Business Case: Ans"atze, Defizite und Perspektiven der deutschsprachigen Betriebswirtschaftslehre. In U. Schneider \& P. Steiner (Eds.), Betriebswirtschaftslehre un Gesellschaftliche Verantwortung: Mit Corporate Social Responsibility zu mehr Engagement (1st ed., pp. 59-83). Wiesbaden, Germany: Gabler Verlag.

Heal, G. (2005). Corporate social responsibility: An economic and financial framework. The Geneva papers on risk and insurance. Issues and Practice, 30(3), 387^1-09.

Hopkins, M. (2003). The planetary bargain. London: Earthscan.

Jaccard, J., \& Turrisi, R. (2003). Interaction effects in multiple regression (2nd ed.). Thousand Oaks: Sage.

Jenkins, H. (2006). Small business champions for corporate social responsibility. Journal of Business Ethics, 67, 241-256.

Jones, C. (2003). As if business ethics were possible: 'Within such limits'.... Organization, 10(2), 223-248.

Jones, T. M. (1995). Instrumental Stakeholder Theory: A synthesis of ethics and economics. The Academy of Management Review, 20(2), 404-437.

Kay, J. (1993). Foundations of corporate success. Oxford: Oxford University Press.

Kong, N, Salzmann, O, Steger, U, \& Ionescu-Somers, A. (2002). Moving business/industry towards sustainable consumption: The role of NGOs. European Management Journal, 20(2), 109-127.

Kramer, M., Pfizer, M., \& Lee, P. (2007). Competitive social responsibility: Uncovering the economic rationale for corporate social responsibility among Danish small- and medium-sized enterprises. Project Report, Copenhagen.

Lantos, G. P. (2001). The boundaries of strategic corporate social responsibility. Journal of Consumer Marketing, 18(2), 595-630.

Lee, M. D. P. (2008). A review of the theories of corporate social responsibility: Its evolutionary path and the road ahead. International Journal of Management Reviews, 10, 53-73.

Longo, M., Mura, M., \& Bonoli, A. (2005). Corporate social responsibility and corporate performance: The case of Italian SMEs. Corporate Governance, 5, 28^-2.

Lowell, B. L. (2007). The new metrics of corporate performance: Profit per employee. The McKinsey Quarterly, 1, 56-65.

Maignan, I., Ferrell, O. C. and Hult, T. G. (1999). Corporate citizenship: Cultural antecedents and business benefits. Journal of the Academy of Marketing Science, 27, 4, 455-469.

Malindi, M. (2009). The impact of the economic downturn on productivity growth. Economic \& Labour Market Review, 3(6), 18-25.

Margolis, J. D., Elfenbein, H. A., \& Walsh, J. P. (2007, August). Does it pay to be good? A meta-analysis and redirection of research on the relationship between corporate social and financial 
performance. Presentation at the Academy of Management Meetings, Philadelphia, PA.

Marin Rives, L., \& Rubio Bañón, A. (2008). ${ }^{\mathrm{A}}$ Moda o factor competitivo? Un estudio empirico de responsabilidad social corporativa en la PYME. Tribuna de Economia, ICE, 842, 177-193.

Maté Sánchez-Val, M. L., et al. (2009). La influencia de los efectos espaciales en el crecimiento de la productividad de la PYME. Estudios de Economia Aplicada, 27(1), 1-24.

McWilliams, A., \& Siegel, D. (2000). Corporate social responsibility and financial performance: Correlation or misspecification? Strategic Management Journal, 21, 603-609.

Mendibil, K., Hernandez, J., Espinach, X., Garriga, E., \& Macgregor, S. (2007). How can CSR practices lead to successful innovation in SMEs? Publication from the RESPONSE Project, Strathclyde, 141

Miles, M. P., \& Covin, J. G. (2000). Environmental marketing: A source of reputational, competitive, and financial advantage. Journal of Business Ethics, 23, 299-311.

Miller, M. L., et al. (2008). Efectos del ausentismo en la productividad de los maestros. Revista Internacional del trabajo, 127(1), 79-98.

Ministry of Industry, Energy and Tourism of Spain. (2012). Retrato de la PYME (pp. 2-3). Accessed February 8, 2012, from http:// estadisticas.ipvme.org/InformesEstadisticos/RetratoPYME2012.pdf

Mintzberg, H. (1983). The case for corporate social responsibility. The Journal of Business Strategy, 4(2), 3-15.

Mintzberg, H. (1993). The rise and fall of strategic planning. New York: Free Press.

Mohr, L., Webb, D., \& Katherine, H. (2001). Do consumers expect companies to be socially responsible? The impact of corporate social responsibility on buying behavior. The Journal of Consumer Affairs, 55(1), 45-67.

Moore, G (2003). Hives and horseshoes, Mintzberg and Mclntyre: What future for corporate social responsibility? Business Ethics: A European Review, 12, 4-55.

Murths, T. P., \& Lenway, S. A. (1998). Country capabilities and the strategic state: How national political institutions affect MNC strategies. Strategic Management Journal, 15(5), 113-119.

Orlitzky, M. (2005). Social responsibility and financial performance: Trade-off or virtuous circle. University of Auckland Business Review, 7, $37 " \bullet 3$

Orlitzky, M., \& Benjamin, J. D. (2001). Corporate social performance and firm risk: A meta-analytic review. Business and Society, 40(4), 369-396.

Orlitzky, M., Schmidt, F. L., \& Rynes, S. L. (2003). Corporate social and financial performance: A meta-analysis. Organization Studies, 24(3), $403^{\mathrm{A}} 41$

Orsato, R (2006). Competitive Environmental Strategies: When Does it Pay to be Green? California Management Review, 48(2), 127-143.

Podolny, J. M. (1993). A status-based model of market competition. American Journal of Sociology, 98, 829-872.

Porter, M. E. (1985). Competitive advantage: Creating and sustaining superior performance. New York: Free Press.

Porter, M. E. (2003). CSR $-A$ religion with too many priests? European Business Forum 15.

Porter, M. E., \& Kramer, M. R. (2002). The competitive advantage of corporate philanthropy. Harvard Business Review, 80(12), 56-69.

Porter, M.E. \& van derLinde, C. (1995).Toward a New Conception of the Environment-Competitiveness Relationship. The Journal of Economic Perspectives, 9(4), 97-118.

Porter, M. E., \& van der Linde, C. (1998). Green and competitive. In M. E. Porter (Ed.), On competition (pp. 351-375). MA Boston: Harvard Business Press.
Rice, P., \& Venables, A. J. (2004). Spatial determinants of productivity, analysis for the regions of Great Britain. Regional Science and Urban Economics, 36(6), 727-752.

Roberts, P. W., \& Dowling, G R. (2002). Corporate reputation and sustained superior financial performance. Strategic Management Journal, 23(12), 1077-1093.

Rondinelli, D. A., \& London, T. (2002). Stakeholder and corporate responsibilities in cross-sectoral environmental collaborations: Building value, legitimacy and trust. In J. Andriof, S. Waddock, B. Husted, \& S. Sutherland Rahman (Eds.), Unfolding stakeholder thinking: Theory responsibility and engagement (pp. 201-215). Sheffield: Greenleaf

Russo, M. V., \& Fouts, P. A. (1997). A resource based perspective on corporate environmental performance and profitability. Academy of Management Journal, 40, 534-559.

Sauian, M. S. (2002). Labour productivity: An important business strategy in manufacturing. Journal of Manufacturing Technology Management, 13(6), 435.

Schaltegger, S., \& Burritt, R. (2005). Corporate sustainability. In H. Folmer \& T. Tietenberg (Eds.), The international yearbook of environmental and resource economics 2005/2006: A survey of current issues (pp. 185-222). Cheltenham: Edward Elgar.

Schnietz, K. E., \& Epstein, M. J. (2005). Exploring the financial value of reputation for corporate responsibility during a crisis. Corporate Reputation Review, 7(4), 327-345.

Schreck, P. (2011). Reviewing the business case for corporate social responsibility: New evidence and analysis. Journal of Business Ethics, 103, 167-188.

Schwaiger, M. (2004). Component and parameter of corporate reputation: An empirical study. Schmalenbach Business Review, 56, 46-71

Sen, S., \& Bhattacharya, C. B. (2001). Does doing good always lead to doing better? Consumer reactions to corporate social responsibility. Journal of Marketing Research, 38(2), 225-243.

Spence, L. J. (1999). Does size matter? The state of the art in small business ethics. Business Ethics: A European Review, 8(3), 163-174

Spence, L. J., Jeurissen, R., \& Rutherfoord, R. (2000). Small business and the environment in the UK and the Netherlands: Toward stakeholder cooperation. Business Ethics Quarterly, 10(4), 945-965.

Spence, L. J., \& Lozano, J. F. (2000). Communicating about ethics with small firms: Experiences from the U.K. and Spain. Journal of Business Ethics, 27(1), 43-53.

Spence, L. J., \& Rutherfoord, R. (2001). Social responsibility, profit, maximization and the small firm owner-manager. Journal of Small Business and Enterprise Development, 8(2), 126-139.

Spence, L. J., \& Rutherfoord, R. (2003). Small business and empirical perspectives in business ethics: Editorial. Journal of Business Ethics, 47(1), 1-5.

Spence, L. J., \& Schmidpeter, R. (2003). SMEs, social capital and the common good. Journal of Business Ethics, 45(1-2), 93-108.

Spence, L. J., Schmidpeter, R., \& Habisch, A. (2003). Assessing Social Capital: Small and medium sized enterprises in Germany and the UK. Journal of Business Ethics, 47(1), 17-29.

Stuebs, M. T., \& Sun, L. (2009). Corporate reputation and technical efficiency: Evidence from the chemical and business services industries. Journal of Applied Business Research, 25(5), 21-29.

Stuebs, M. T., \& Sun, L. (2010). Business reputation and labour efficiency, productivity, and cost. Journal of Business Ethics, 96, 265-283.

Sullivan, A., \& Sheffrin, S. M. (2003). Economics: Principles in action. Upper Saddle River, NJ: Pearson Prentice Hall.

Taymaz, E. (2002). Are small firms really less productive? An analysis of productivity differentials and firms dynamics. Small Business Economics, 25, $\mathbf{4 2 9}^{\mathrm{A}}-\mathbf{4 5}$. 
Thompson, J. K., \& Smith, H. L. (1991). Social responsibility and small business: Suggestions for research. Journal of Small Business Management, 29(January), 30-44.

Tilley, F. (2000). Small firm environmental ethics: How deep do they go? Business Ethics: A European Review, 9(1), 31-41.

Tödtling, F., \& Kaufmann, A. (2001). The role of the region for innovation activities of SMEs. European Urban and Regional Studies, 8(3), 203-215.

Toyne, P. (2003, June 15-18). Corporate social responsibility—Good business practice and a source of competitive edge for SMEs? Paper presented at the 48th World conference international council for small business (ICSB): Advancing entrepreneurship and small business, Belfast, Northern Ireland.

Turban, D. B., \& Greening, D. W. (1997). Corporate social performance and organizational attractiveness to prospective employees. Academy of Management Journal, 40(3), 658-672.

van Luijk, H. J. L. (1999). Business ethics in Europe: A tale of two efforts. In R. E. Frederick (Ed.), A companion to business ethics (pp. 353-365). Cambridge, MA: Blackwell.

van Luijk, H. J. L. (2005). Etica empresarial: ${ }^{\wedge}$ Hasta dónde hemos llegado? Una perspectiva europea. ICADE Revista cuatrimestral de las Facultades de Derecho y Ciencias Económicas y Empresariales de la Universidad Pontificia Comillas de Madrid, 64, 11-32.

Vicente Molina, A., et al. (2004). Compatibilidad entre responsabilidad social corporativa y competitividad: estado de la cuestión en el dmbito internacional (pp. 99-100). Basque: Institute de Economia Aplicada a la empresa, Pais Vasco University.

Viladecans, E., \& Costa, M. (1999). Concentratión geográfica de la industria e integratión económica de España. Economia Industrial, 329, 19-28.
Vilanova, M., Lozano, J., \& Arenas, D. (2009). Exploring the nature of the relationship between CSR and competitiveness. Journal of Business Ethics, 87, 57-69.

Vyakarnam, S., Bailey, A., Myers, A., \& Burnett, D. (1997). Towards an understanding of ethical behaviour in small firms. Journal of Business Ethics, 16(15), 1625-1636.

Waddock, S. A., \& Graves, S. B. (1997). The corporate social performance-financial performance link. Strategic Management Journal, 18(4), 303-319.

Wartick, S. L., \& Cochran, P. L. (1985). The evolution of the corporate social performance model. Academy of Management Review, 10, 758-769.

Weber, M. (2008). The business case for corporate social responsibility: A company-level measurement approach for CSR. European Management Journal, 26, 247.

Welford, R. (2003). Beyond systems: A vision for corporate environmental management for the future. International Journal of Environment and Sustainable Development, 2, 162-173.

Williamson, D., et al. (2006). Drivers of environmental behaviour in manufacturing SMEs and the implications for CSR. Journal of Business Ethics, 67(3), 317-330.

Wood, D. J. (1991). Corporate social performance revisited. Academy of Management Review, 16, 691-718.

Wood, D. J. (2010). Measuring corporate social performance: A review. International Journal of Management Reviews, 12, 50-84.

Woodward, D., Edwards, P., \& Birkin, F. (2001). Some evidence on executives' views of corporate social responsibility. British Accounting Review, 33, 357-397.

Wu, M. (2006). Corporate social performance, corporate financial performance, and firm size: A meta-analysis. Journal of American Academy of Business, 8(1), 163-171. 